\title{
Use of Digital Storytelling in Biology Teaching
}

\author{
Ferit Karakoyun ${ }^{1, *}$, I.Ümit Yapıcı \\ ${ }^{1}$ Department of Computer Education and Instructional Education, Dicle University, Turkey \\ ${ }^{2}$ Department of Biology Education, Dicle University, Turkey
}

Copyright $(2016$ by authors, all rights reserved. Authors agree that this article remains permanently open access under the terms of the Creative Commons Attribution License 4.0 International License

Abstract With the technological developments in the $21^{\text {st }}$ century, it is now necessary to integrate technological renovations effectively into teaching-learning environments. There are several approaches that allow integration of technology into teaching-learning environments. One of these approaches is digital storytelling. The purpose of this study was to examine preservice teachers' views about the use of digital storytelling in biology teaching as an instructional tool. The study group included 16 third grade preservice teachers attending the Department of Biology Teaching at the Ziya Gökalp Education Faculty at Dicle University. The preservice teachers, who took part in digital storytelling activities which were carried out in four weeks in the Spring Term of the academic year of 2014-2015, formed their own digital stories at the end of the activities. Following the activities, the preservice teachers were asked for their views about the use of digital storytelling in biology teaching. According to the results of the study, the preservice teachers reported that use of digital storytelling in lessons could increase students' learning. Also, the preservice teachers stated that digital storytelling activities were entertaining; that these activities could attract students' attention; and that students could take an active role during the activities. On the other hand, regarding the limitations of the use of digital storytelling, the preservice teachers pointed out that digital storytelling allows transferring limited information. Consequently, the preservice teachers stated that they wanted to use digital storytelling process in future because it allowed learning by doing and living, added visuality to biology lessons, and made learning permanent.

Keywords Digital Storytelling, Biology Teaching, Technology Integration

\section{Introduction}

Technology has become an important part of teaching-learning environments as well as of our lives in recent years. With the importance of technology use in education, there is a special emphasis on the integration of technology into teacher training and professional development [1, 2]. However, although computers, mobile devices and interactive technologies are quite common in today's classrooms, it is seen that teachers lack the necessary skills and knowledge regarding how to integrate these technologies into curricula $[3,4,5,6,7]$. It is an important necessity for teachers to have technology use skills, yet it is more important to provide teachers with training on how to make use of these skills to support their teaching [8].

While educational settings in which technology is effectively integrated not only help students take active part in their learning environments but also allow transferring the instructional content effectively, these settings also develop many skills of students [9, 10, 11]. For this reason, today, technology is intensively used in educational environments, and there is a need for new methods and techniques to increase students' participation in classes and to structure their current knowledge. In this respect, digital storytelling is considered to be an effective tool for this purpose.

\subsection{Digital Storytelling}

Digital storytelling serves as a popular pedagogical tool to be used by teachers in different fields for students from all age groups, from education levels and from any ethnic origin [12]. Although there are several definitions of digital storytelling, these definitions generally include the combination of the art of storytelling and such multimedia elements as images, audios and videos [13]. Lambert [14], an expert on digital stories, determined seven elements for the production of effective digital stories: perspective, striking question, emotional content, use of audios, music, and economy and pacing. When related literature is examined, it is seen that there are various types of digital stories. However, Robin [13] gathered the types of digital storytelling under three main headings: informative and instructive stories, personal stories and stories about historical events. Digital stories may vary in length, but most of them last between two and ten minutes [15].

The process of producing a digital story requires students first to determine a subject, to research the subject, and to form a scenario within the framework of their research. Following this, the process requires students to associate their scenarios with such multimedia elements as images, 
music and graphics and to form short stories by using several softwares [16, 17]. Students completing the process of digital storytelling process can share their stories with a certain audience in class or on the Internet [18, 19]. Sharing of digital stories could help students understand each other and show empathy towards one another [19]. In addition, it also allows students to get information about a number of subjects [20,21].

\subsection{Advantages of Digital Storytelling}

Activities carried out in the process of digital storytelling in class environment rescue students from the passive position and transform them into active participants in the learning process [22, 23]. Boster, Meyer, Roberto and Inge [24] state that use of multimedia materials in teaching not only allows students to get new information but also is acts as an effective method that helps students understand the instructional content.

Teachers can use digital storytelling in class environment to teach a certain subject [15]. Robin [16] points out that digital storytelling can be put into practice in class to teach subjects especially related to history, science and mathematics. Using the digital storytelling approach in class, teachers can both provide the environment necessary to keep students' interest live and help create an educational environment different from traditional ones [25]. Burmark [26] reports that digital storytelling is a beneficial technological tool to collect, analyze and present information and that integrating visuals into written texts will facilitate students' understanding. A digital story including rich multimedia elements helps draw students' attention and encourages them to investigate new subjects [16]. The digital storytelling approach is also regarded as a multifaceted learning approach since it requires intensive use of technology, written communication, verbal communication, critical thinking and critical reading $[27,28,29]$. To sum up, digital storytelling, with it's all other positive aspects which allows technology integration and which reflect upon educational environments, can be used effectively in the teaching and learning process [30].

\subsection{Digital Storytelling and Biology Education}

It is quite difficult to teach and learn biology as it includes complex relationships of unfamiliar and abstract concepts. The fact that biology concepts are abstract and complex in biology teaching causes students to have difficulty understanding certain subjects and to learn by memorizing them [31]. In order to overcome this problem, the importance of use of information and communication technologies is gradually increasing. Visual presentation of information with the help of computers is quite important in biology teaching. Well-prepared images, three-dimensional models, animations, interactive environments allow understanding the target information more easily [32]. In this respect, digital storytelling could be regarded as an important tool for teaching biology subjects effectively. Sadik [21] states that use of digital storytelling in the teaching of mathematics and science is an effective method although it is mostly related to art and humanities. Hung, Hwang and Huang [23] reported that use of digital storytelling in science education increases students' motivation and success.

\subsection{Significance of the Study}

Considering the advantages of digital storytelling, developing digital storytelling activities in the education process could be said to help teachers develop their vision of technology integration and to help transfer the instructional content effectively by allowing students to take active part in learning environments. In addition, it is seen that digital storytelling develops many skills of students. In this respect, the present study, which was carried out on the use of digital storytelling in biology teaching, is thought to contribute to the development of biology preservice teachers' competencies regarding technology integration. In addition, when studies in related literature are examined, it is seen that there is no research conducted on the use of digital storytelling in the field of biology teaching. For this reason, the present study is believed to take a leading role in the field. In this respect, the purpose of this study was to investigate preservice teachers' views about the use of digital storytelling as an instructional tool in biology teaching. For this purpose, the following research questions were directed in the study:

1. What are biology preservice teachers' views about the advantages of use of digital storytelling in biology teaching?

2. What are biology preservice teachers' views about the limitations of digital storytelling in biology teaching?

3. What are biology preservice teachers' suggestions regarding the use of digital storytelling in biology teaching?

\section{Materials and Method}

In the present study, a descriptive model, one of research models which aim at describing a current situation, was used. For the collection, analysis and interpretation of the research data, qualitative research methods were applied.

\subsection{Participants}

The participants in the study were 16 third-grade preservice teachers taking the course of Instructional Technologies and Material Design in the Department of Biology Teaching at Ziya Gökalp Education Faculty at Dicle University in the Spring Term of the academic year of 2014-2015. While determining the participants, purposeful sampling method was used in line with the research purposes. 


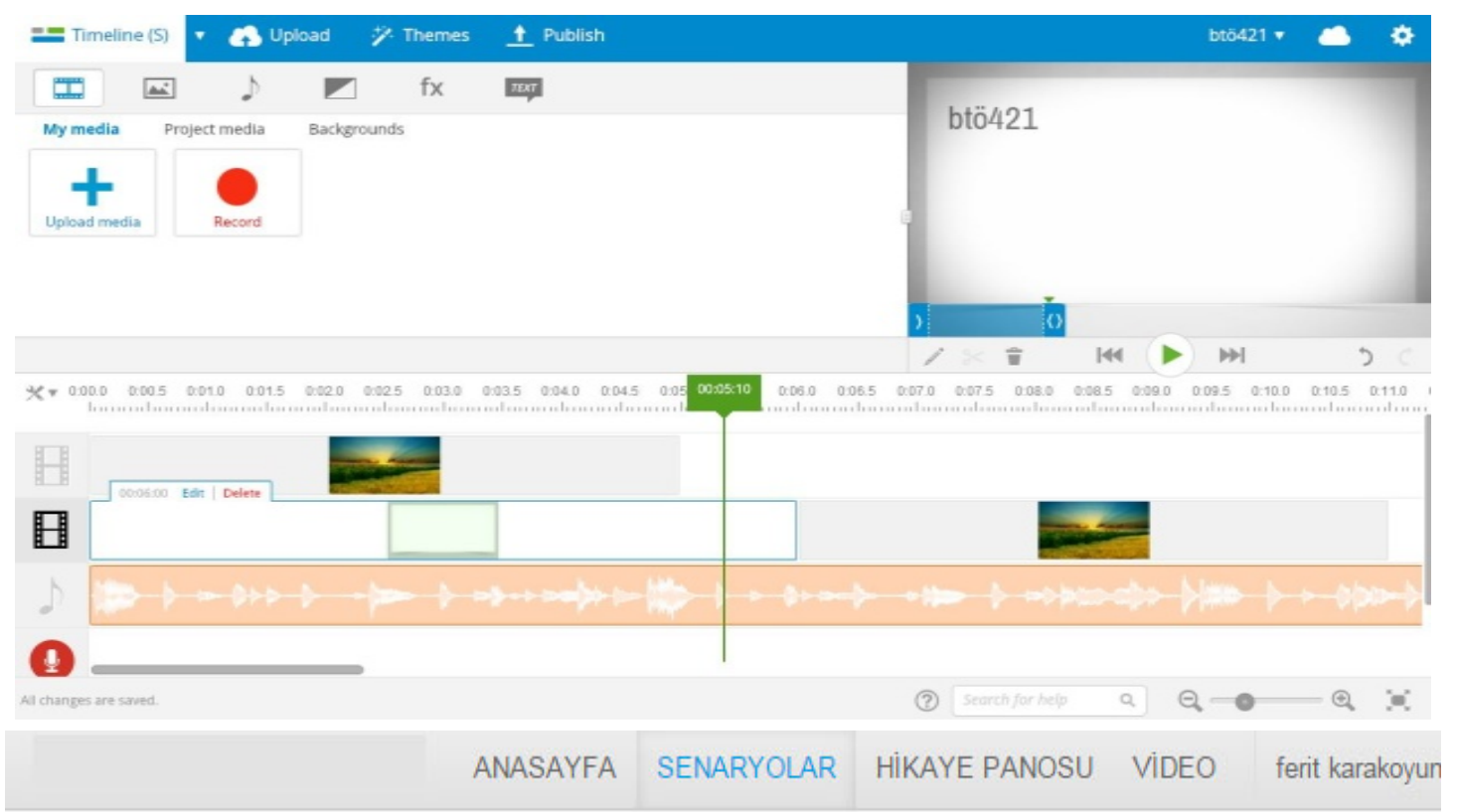

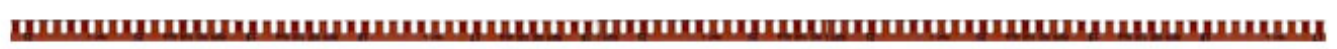

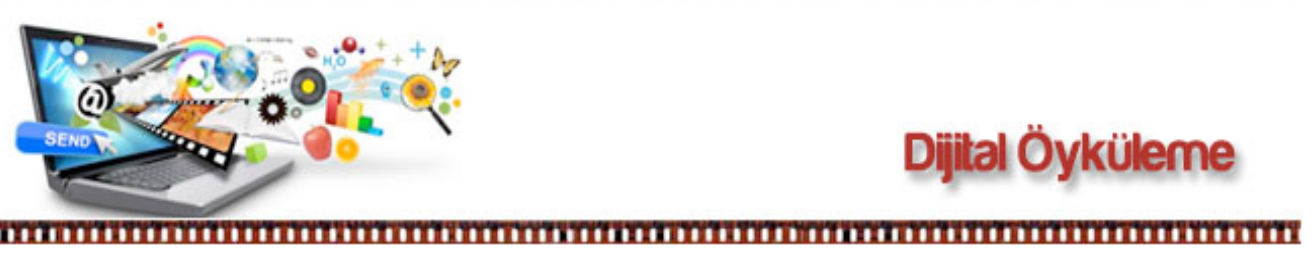

Senaryo Ekle

Sınıf seç:

Listele

Şu anda 6 / B sınıfı görüntülenmektedir.

Adı Soyadı: G

Sınıfı: $6 / B$

Eliniz tek çizgili mi?

"Hayır! iki,üç" dediğinizi duyar gibiyim. Peki Heidi' nin eli neden tek çizgili? Heidi bunu arkadașlarıyla parkta oynarken fark etti. Üstelik yalnız bunu değil; gözlerinin badem şekli, kısa ve küt parmaklarını, dilinin büyük ve sarkıklığını, boynunun kalınlığının arkadaşları

Görüntüle

Adı Soyadı: h

Sınıfi: $6 / B$

Dünyada en çok korktugunuz hayvan nedir ? Bi böcek mi kus mu yoksa havlayan bir köpek mi ? Belki de onlardan korkmuyoruz. Keskin pençeler, sivri dişler, boynuzlar ve dikenlerin hepsi öldürmek için ideal birer silahtır. Çok güçlü olmanız yada silahlara sahip olmanız sizi bir çoğuna karşı koruyabilse de, belki de

Görüntüle

Figure 1. Digital storytelling webpage and Wevideo 


\subsection{Research Procedures}

In the research process, "Wevideo (www.wevideo.com)", an online video editing software with a simple interface, cloud technology and other effective features, was used to help the preservice teachers edit their digital story videos in online environment. In addition, a web page which was developed by the researcher with a domain name of "www.dijitaloykuleme.com" to allow the students to carry out their digital storytelling activities and to share the videos they formed in online environment was used. The "digital storytelling webpage" was used in such phases of digital storytelling process as developing a scenario, forming a story board and sharing the digital stories and the "Wevideo webpage" was used in the phase of video editing. Figure 1 demonstrates screenshots for "Wevideo" and "Digital Storytelling Webpage".

The research process lasted 16 hours in four weeks. First of all, a total of 16 third-grade students from the Department of Biology Teaching were provided with training on digital storytelling and on the use of online softwares. Following this training, the preservice teachers determined the biology-related subjects to create their digital stories and conducted research on these subjects. The preservice teachers completing the research process not only formed their draft scenarios regarding the subjects they determined but also uploaded these scenarios on the digital storytelling webpage. After forming the draft scenario, the preservice teachers provided feedback to each other's scenarios via the digital storytelling webpage. In the following phase, the preservice teachers searched for such multimedia materials as photos, pictures, music and videos via the Internet and other environments in relation to their scenarios and voiced their scenarios. The students who not only determined the multimedia materials they would use for their scenarios but also completed the process of voicing their scenarios formed their story boards. Lastly, the preservice teachers organized the multimedia materials and voicings regarding their scenarios in Wevideo environment and shared their digital story videos on YouTube as well as on the digital storytelling webpage. Table 1 presents the research process.

\subsection{Data Collection Tools}

The research data were collected via an interview form made up of 5 open-ended questions directed to 16 students attending the Department of Biology Teaching at Ziya Gökalp Education Faculty at Dicle University.

\subsection{Data Analysis}

The qualitative data collected in the study were analyzed with the content analysis method. In content analysis, the basic purpose is to reach concepts and relationships that allow explaining the data collected. Content analysis helps define the research data and reveal the facts likely to be hidden in the data [33]. The data collected from the biology preservice teachers were analyzed by the researchers using the software of NVivo 11.0 and were evaluated within the framework of themes including the advantages of digital storytelling in biology teaching, its limitations, and the suggestions regarding the use of digital storytelling.

Table 1. Research Process

\begin{tabular}{|c|c|c|c|}
\hline Week 1 & Information about the process & $\begin{array}{c}\text { Definition of digital storytelling and the } \\
\text { digital storytelling process }\end{array}$ & $\begin{array}{c}\text { Information about the use of } \\
\text { "Wevideo" and "digital storytelling } \\
\text { webpage" }\end{array}$ \\
\hline Week 2 & $\begin{array}{c}\text { Determining the subjects related to } \\
\text { biology }\end{array}$ & $\begin{array}{r}\text { Investigating the content for the subjects } \\
\text { determined }\end{array}$ & $\begin{array}{c}\text { Developing the scenario and sharing it } \\
\text { on the digital storytelling webpage }\end{array}$ \\
\hline Week 3 & $\begin{array}{c}\text { Feedback provided by other students to } \\
\text { the scenarios via the webpage, and } \\
\text { finalizing the scenarios }\end{array}$ & $\begin{array}{c}\text { Searching for multimedia materials such as } \\
\text { pictures, videos and music related to the } \\
\text { scenarios, and voicing the scenarios }\end{array}$ & Forming the story board \\
\hline Week 4 & $\begin{array}{c}\text { Uploading the multimedia materials on } \\
\text { Wevideo environment }\end{array}$ & $\begin{array}{c}\text { Organizing and finalizing the multimedia } \\
\text { materials in Wevideo environment and } \\
\text { sharing them on YouTube }\end{array}$ & $\begin{array}{c}\text { Transferring YouTube videos into } \\
\text { Wevideo environment and students" } \\
\text { evaluation of the videos }\end{array}$ \\
\hline
\end{tabular}




\section{Findings}

It was seen that the digital stories formed by the biology preservice teachers were related to such subjects as color blindness, down syndrome, skeleton, mutualism, dangerous animals, heart, spider webs, features of a cell, why people cry when they are born?, origin of the name of narcissus, Adam's apple, chromosomes determining the gender of a newborn baby, human immune system, and the female scorpion's eating the male scorpion.

\subsection{Advantages of Digital Storytelling}

When the biology preservice teachers' views about the advantages of digital storytelling were examined, it was seen that digital storytelling contributed to the permanency of what they learned, increased their learning and allowed making use of multimedia elements as well as use of imagination. In addition, the preservice teachers reported that they were more active in these environments; that the digital storytelling activities were entertaining; that these activities could draw their attention and develop their research skills; and that the activities increased the student-teacher relationship, helped take responsibility and acquire the technology skills, supported learning by doing and living, contributed to learning new things and allowed saving time.

The preservice teachers mostly stated that use of multimedia elements in the digital storytelling process would contribute to the permanency of the subjects learned and that this would increase students' learning. In addition, they reported that the process could facilitate teaching. Regarding this point, A1, one of the participants, said "it would be easier to teach difficult subjects, and it would be more permanent as it is both visual and auditory." A3 said "use of such elements as videos, audios and images would contribute to permanency of learning the subjects difficult to understand". Another participant, A2, said "Because it helps the teacher with the teaching of the subject, it will facilitate teaching."

The other points agreed on by most of the preservice teachers included the fact that the digital storytelling process created an entertaining environment; that it could draw the students' attention as was a different technique of teaching; and that students would take an active role in the process. Among the preservice teachers, A4 said "This process could make a subject that student's hate or find boring more entertaining. Also, it would create an entertaining environment for both the teacher and the students." Another participant, A5, said "The process would draw the attention of students since the teacher applied a different teaching technique." A2 said "Most importantly, the process makes students active in the learning environment."

Another common point made by the preservice teachers was the fact that the digital storytelling process would help save time in the teaching and learning process since it would take less time to teach a subject. Among the preservice teachers, A7 said "It helps save time. We can teach the subject in a shorter period of time". Another participant, A8, said "It is effective in terms of teaching and understanding a subject more quickly."

Some of the preservice teachers reported that creating a digital story could develop students' technology use skills. One of the preservice teachers, A9, stated that the students used technology intensively and effectively, saying "Digital storytelling requires use of technology and helps learn how to use technology in such situations. It also helps both the teacher and the students learn how to use technology effectively and productively." Another preservice teacher, A10, stated that students became aware of their responsibilities in the digital storytelling process and that they did their best while carrying out their tasks, saying "Students take responsibility thanks to digital storytelling because they have a job to do in the process. They will certainly do their best to achieve it."

\subsection{Limitations of Digital Storytelling}

When the biology preservice teachers' views about the negative aspects of digital storytelling were examined, it was seen that subjects are taught superficially in the digital storytelling process; that it was not possible to adopt digital storytelling to all subjects; and that different readiness levels of the students would have negative influence on the process.

The preservice teachers mostly reported that digital storytelling did not allow presenting detailed information about subjects and those students were provided with superficial information about subjects. In relation to this point, one of the participants, A8, said "As digital stories are short, the teacher cannot provide students with detailed information about the subject". Another participant, A1, said "As you cannot teach the details about the subject, students may not develop their knowledge about that subject."

Some of the preservice teachers stated that it would not be possible to adopt digital storytelling to all subjects. One of the preservice teachers, A11, reported that the digital storytelling approach could be applied to some subjects in the teaching and learning process while use of supplementary materials or methods would be necessary for the teaching of certain subjects, saying "Digital storytelling may not be applied to all subjects. For example, while teaching the subject of respiration, the steps involved should be written on the board in class besides the use of other related visuals". Some of the preservice teachers stated that they had difficulty finding sources (pictures, videos and so on) related to the subject about which digital stories were created. In relation to this, one of the preservice teachers, A12, said "while preparing my story, lack of related sources was a real problem for me."

Some of the preservice teachers reported that different readiness levels of students in the digital storytelling process would have negative influence on teachers. In relation to this, one of the preservice teachers, A15, said "As a negative aspect of this for the teacher, a hundred percent teaching 
may not be achieved since not all students will have equal learning levels". Some other preservice teachers stated that students' lack of efficient technology skills may cause students to have difficulty and problems in the digital storytelling process. One of the preservice teachers, A7ü, said "students who do not know how to use a computer may experience problems while preparing a video."

\subsection{Suggestions Regarding the Use of Digital Storytelling}

When the preservice teachers' suggestions regarding the use of digital storytelling in biology teaching were examined, it was seen that they believed in the necessity to increase the lengths of videos prepared in the digital storytelling process, to exclude the story board from the digital storytelling process, to use digital stories for the purpose of repetition, to do group work and to share videos on social network websites.

The preservice teachers mostly reported that the lengths of videos prepared in the digital storytelling process were not sufficient enough to understand the biology subjects and that the video lengths could thus be increased. In relation to this, one of the participants, A1, said "The videos are quite short, and thus, there is lack of necessary information. The duration of videos could be increased for the biology subjects."

Some of the preservice teachers stated that they already organized the multimedia elements with the help of the software; that forming the story board was unnecessary; and that the story board could thus be excluded from the digital storytelling process. One of the students, A11, said "I think the story board is not necessary in the process of preparing a digital story because we already organize the photos and audio records while preparing the video. Thus, the story board could be removed."

Among the preservice teachers, some of them reported that digital stories should be used in class for repetition purposes. One of the preservice teachers, A6, mentioned the need for preparing a digital story for repetition purposes following the teacher's presentation of the subject in traditional ways, saying "For example, the teacher teaches a subject traditionally. In the following weak, the teacher can increase the permanency of students' learning by having them watch a related digital story prepared in advance. Instead of directly having the students watch the digital story, the teacher can use this video for repetition purposes."

\section{Which Biology Subjects Is Digital Storytelling Appropriate to?}

The biology preservice teachers stated that digital storytelling could be more appropriate to such biology subjects as living beings, systems, structure of DNA, mitotic and meiosis division, photosynthesis, cell, heredity and reproduction. It was seen that the preservice teachers considered digital storytelling to be especially appropriate to the subjects of cell, living beings and systems. One of the preservice teachers, A7, stated that the subject of cell in biology was quite important and that the functions of organelles in a cell could be taught with the help of a related digital story. In relation to this, A7 said "It is the lesson subject of cell because in biology, visuality is important. For example, the teacher can show the organelle in a cell and talk about their functions." In addition, another preservice teacher, A3, pointed out that biology is a science of living beings and that digital stories could be used to get information and images regarding living beings, saying; "Biology is a science of living beings, and in such a large scientific field, there are numerous species of living beings. Digital stories could be used to obtain information and images regarding these living beings." Another preservice teacher, A1, pointed out that digital storytelling should be applied to the subject of systems, saying "It should especially be applied to systems. For example, the teacher can show all the organs in the digestive system tell their functions and show their places in the human body."

\section{Will You Use Digital Storytelling in Future?}

All the biology preservice teachers stated that they would like to use digital storytelling in their courses in future. The preservice teachers reported that they considered using the digital storytelling technique in their future educational instructions since digital storytelling activities to be carried out especially in biology classes allowed students to learn by doing and living, created an entertaining environment, contributed to visuality and made learning more permanent. One of the preservice teachers, A12, said "I believe students will understand the lessons better since they learn by doing and living in biology classes. Therefore, I think I will use it in my future career." Some of the preservice teachers stated that they wanted to use digital storytelling in future because it created an entertaining environment for students in biology classes. One of the preservice teachers, A14, said "I am thinking of using digital storytelling in future. Rather than teaching with traditional methods, teaching a subject in an entertaining manner will facilitate students' learning."

Some of the preservice teachers believed that digital storytelling activities would increase learning as they would made students' learning permanent by concretizing abstract information about biology subjects. One of the preservice teachers, A9, said "With the help of digital stories, which help concretize certain abstract concepts in biology that students have difficulty understanding, they will be able to learn these concepts more easily". One of the preservice teachers, A1, pointed out that students would learn biology lessons more easily when visuals were involved in biology teaching, saying "storytelling can be applied to biology subjects because many subjects in biology are appropriate to the use of visuals. Digital stories will increase permanency and contribute to students' understanding because they are both visual and auditory".

\section{Conclusion and Discussion}

In the present study, which examined the use of digital 
storytelling in biology teaching, it was seen that the biology preservice teachers mostly had positive views about digital storytelling and that they would like to use this technique in lessons in their future teaching life.

The findings about the advantages of digital storytelling in the study revealed that the preservice teachers thought use of digital storytelling in classes will help make students' learning more permanent and increase their learning. Similarly, in one study carried out in the field of language teaching, Foley [15] reported that students' field knowledge and their academic achievements increased thanks to use of digital storytelling. According to Gakhar [34], digital storytelling activities allow students to increase their knowledge about the subjects they investigate. Other studies demonstrated that digital storytelling help students learn a great amount of information about real phenomena or about a curriculum $[20,13,21]$.

The preservice teachers stated that the digital storytelling activities created an entertaining learning environment in class; that this entertaining environment could draw students' attention; and that they could take an active role during the activities. In a related study carried out by Wang and Zhan [35], the researchers reported that digital storytelling activities provided active, reflective and entertaining opportunities for learning in class.

The preservice teachers also pointed out that the digital storytelling approach allowed saving time in the teaching and learning process it helped provide more information about the lesson subjects in a shorter period of time. On the other hand, when the related literature is reviewed, it is seen that within the context of technology integration, use of digital storytelling in class was a time-consuming process. In relation to this, Robin [13] stated that preparing a story by gathering the necessary components in the digital storytelling process was a time-consuming process. In another study, teachers reported that they could not find the necessary time to carry out digital storytelling activities in class [36]. Several other studies in related literature revealed that time constraint constitutes an important obstacle for technology integration [37,38,6,39]).

In the study, the preservice teachers stated that students' technology use skills could be developed as they were always hand in hand with technology in the digital storytelling process. In relation to this, Dogan [27] claimed that digital storytelling mostly developed students' technology skills and media literacy. Other related studies demonstrated that students can structure their knowledge in the digital storytelling process and that they develop their technology use skills as they use several computer programs and technological tools $[40,16,41]$.

The preservice teachers also reported that students could take responsibility in the digital storytelling process and accomplish the tasks assigned to them. In a related study, preservice teachers stated that digital storytelling is a process requiring responsibility and that students' responsibility skills develop since they are supposed to carry out certain duties in the process [42]. Tatum [43] reported that students raise their consciousness of activities in the digital storytelling process with the passing of time.

On the other hand, in relation to the limitations of use of digital storytelling in class, the preservice teachers mostly stated that digital storytelling allowed limited presentation of information. The preservice teachers might have believed so because they thought the video lengths of the digital stories they created in the digital storytelling process were short. In addition, some of the preservice teachers pointed out that use of digital storytelling might not be appropriate to all biology subjects, while some of them stated that different readiness levels of the students in the digital storytelling process might have negative reflections upon teachers cause students to experience difficulty in the process. Some of the preservice teachers stated that they failed to find enough sources necessary for the lesson subjects in the digital storytelling process. For this reason, they might have thought that use of digital storytelling was not appropriate to all biology subjects. In addition, the preservice teachers' belief that students' readiness levels might reflect negatively upon the process of creating digital stories could be due to the fact that the students who would create a digital story might not have the necessary technological skills. Yuksel [44] stated that teachers should take students' age and their individual differences into consideration while using technology in their education process.

When the findings about preservice teachers' suggestions were examined, the preservice teachers stated that the digital story videos were not long enough to teach the biology subjects and that the lengths of the videos to be prepared in the digital storytelling process could be increased. Some of the preservice teachers reported that it was unnecessary to form a story board in the digital storytelling process and that the story board could be excluded from the digital storytelling process. On the other hand, Jakes and Breannan [19] claimed that the process of forming a story board is a necessary component of the digital storytelling process although it is a step which most students hate and which teachers generally skip in the process.

In relation to the biology subjects that use of digital storytelling activities was most appropriate to, the preservice teachers counted such subjects as living beings, systems, structure of DNA, mitotic and meiosis division, photosynthesis, cell, heredity and reproduction. The preservice teachers pointed out that digital storytelling would be appropriate especially to the subjects of cell, living beings and systems.

Lastly, the preservice teachers reported that they would like to use digital storytelling activities in future as these activities allow students to learn by doing and living, created an entertaining environment, included visuality in biology subjects, and made students' learning more permanent. Dogan and Robin [45], in their study with elementary school teachers, demonstrated that all the participants had the intention to use digital storytelling activities in their classes in future. 


\section{REFERENCES}

[1] Lawless, K. A., \& Pellegrino, J. W. (2007). Professional development in integrating technology into teaching and learning: knowns, unknowns, and ways to pursue better questions and answers. Review of Educational Research, 77 (4), 575

[2] Mandell, S., Sorge, D. H., \& Russell, J. D. (2002). Tips for technology integration. TechTrends, 46(5), 39-43.

[3] Rosenberg, M. G. (2015). Supporting learner-centered technology integration through situated mentoring (Order No. 3702215).. (1682480011). Retrieved from http://search.proq uest.com/docview/1682480011?accountid $=15780$

[4] Abbott, L. (2005). The nature of authentic professional development during curriculum-based tele-computing. Journal of Research on Technology in Education, 37(4), 379-398.

[5] Sulcic, V., \& Lesjak, D. (2009). E-learning and study effectiveness. Journal of Computer Information Systems, 49(3), 40-47.

[6] Norris, C., \& Soloway, E. (2011). The 10 barriers to technology adoption. District Administration, 47/10. Retrieved fromhttp://www.districtadministration.com/article /10-barrierstechnology-adoption

[7] Ogwu, E. N., \& Ogwu, F. J. (2010). Technologies and utilization in schools: Its implications to learning. Journal of Technology Integration in the Classroom, 2(1), 49-57.

[8] Lin, C., \& Lu, M. (2010). The study of teachers' task values and self-efficacy on their commitment and effectiveness for technology-instruction integration. US-China Education Review, 7(5), 1-11.

[9] Brown, K. (2004). Technology: Building interactions. TechTrends, 48(5), 36-38

[10] Kulik, J. (2003). Effects of using instructional technology in elementary and secondary schools: What controlled evaluation studies say? (SRI Project No. P10446.001). Arlington, VA: SRI International.

[11] Ware, P. D. (2006). From sharing time to showtime! Valuing diverse venues for storytelling in technology-rich classrooms Language Arts, 84 (1), 45-54.

[12] Garcia, P. A., \& Rossiter, M. (2010). Digital storytelling as narrative pedagogy. In D. Gibson and B. Dodge (Ed.), Proceedings of Society for Information Technology \& Teacher Education International Conference 2010 (pp. 10911097). Chesapeake, VA: AACE.

[13] Robin, B. (2006). The Educational Uses of Digital Storytelling. In C. Crawford et al. (Ed.), Proceedings of Society for Information Technology \& Teacher Education International Conference, 2006 (pp. 709-716). Chesapeake, VA: AACE.

[14] Lambert, J. (2010). Digital storytelling cookbook and traveling companion. Berkeley, CA: Digital Diner Press.

[15] Foley, L. M. (2013). Digital storytelling in primary-grade classrooms (Unpublished doctoral dissertation), Arizona
State University.

[16] Robin, B. R. (2008). Digital storytelling: A powerful technology tool for the 21 st century classroom. Theory Into Practice, 47, 220-228.

[17] Bull, G., \& Kajder, S. (2004). Digital storytelling in the language arts classroom. Learning \& Leading with Technology, 32 (4), 46-49.

[18] Barrett, H. (2009). How to create simple digital stories. Retrieved from http://electronicportfolios.com/digistory/how to.html

[19] Jakes, D.S., \& Brennan, J. (2005). Capturing stories, capturing lives: An introduction to digital storytelling. Retrieved from http://bookstoread.com/etp/earle.pdf.

[20] Malita, L., \& Martin, C. (2010). Digital Storytelling as web passport to success in the 21 st Century. Procedia - Social and Behavioral Sciences, 2(2), 3060-3064.

[21] Sadik, A. (2008). Digital storytelling: A meaningful technology-integrated approach for engaged student learning. Educational Technology Research and Development, 56, 487-506.

[22] Howell, \& Howell (2003). What is your digital story?. Library Media Connection, 22(2), 40.

[23] Hung, C.-M., Hwang, G.-J., \& Huang, I. (2012). A project-based digital storytelling approach for improving students' learning motivation, problem-solving competence and learning achievement. Educational Technology \& Society, 15 (4), 368-379.

[24] Boster, F. J., Meyer, G. S., Roberto, A. J., \& Inge, C. C. (2002). A report on the effect of the united streaming application on educational performance. East Lansing, MI: Cometrika, Inc., Baseline Research, LLC., \& Longwood University.

[25] Jenkins, M., \& J. Lonsdale. (2007). Evaluating the effectiveness of digital storytelling for student reflection. ASCILITE conference (pp.440-444). Singapore.

[26] Burmark, L. (2004). Visual presentations that prompt, flash \& transform. Media and Methods, 40(6), 4-5.

[27] Dogan, B. (2012). Educational uses of digital storytelling in K-12: Research results of digital storytelling contest (DISTCO) 2012. In P. Resta (Ed.), Proceedings of Society for Information Technology \& Teacher Education International Conference 2012 (pp.1353-1362). Chesapeake, VA: AACE.

[28] Gregory, K., \& Steelman, J. (2008). Digital storytelling: Powerful student engagement with multiple benefits. Paper presented at the annual meeting of the National Association of Developmental Education, Greensboro, NC.

[29] Yang, Y. T. C., \& Wu, W.C. I. (2012). Digital Storytelling for enhancing student academic achievement, critical thinking, and learning motivation. A year - long experimental study. Computers \& Education, 59(2), 339- 352.

[30] Educause Learning Initiative (2007). 7 things you should know about ... digital storytelling. Retrieved from http://net. educause.edu/ir/library/pdf/ELI7021.pdf

[31] Kılıç, D., \& Sağlam, N. (2004). Biyoloji eğitiminde kavram haritalarının öğrenme başarısına ve kalıcılığına etkisi. Hacettepe Üniversitesi Ĕgitim Fakültesi Dergisi, 27, 
155-164.

[32] Çömlekçioğlu, U., \& Bayraktaroğlu, E. (2001). Biyoloji ve Bilişim Teknolojileri. Kahramanmaraş Sütçü Imam Üniversitesi Fen ve Mühendislik Dergisi, 4 (1), 63-73.

[33] Yıldırım, A., \& Șimșek, H. (2011). Sosyal bilimlerde nitel araştırma yöntemleri (8. Baskı). Ankara: Seçkin Yayıncılık.

[34] Gakhar, S. (2007).The influence of digital storytelling experience on pre-service teacher education students attitudes and intentions. Masters Abstracts International, $46(1)$.

[35] Wang, S., \& Zhan, H. (2010). Enhancing teaching and learning with digital storytelling. International Journal of Information and Communication Technology Education (IJICTE), 6 (2), 76 - 87.

[36] Dogan, B. (2007). Implementation of digital storytelling in the classroom by teachers trained in a digital storytelling workshop (Unpublished doctoral dissertation), University of Houston.

[37] Hew, K., \& Brush, T. (2007). Integrating technology into K-12 teaching and learning: Current knowledge gaps and recommendations for future research. Educational Technology Research and Development, 55(3), 223-252.

[38] Keengwe, J., Onchwari, G., \& Wachira, P. (2008). Computer technology integration and student learning: barriers and promise. Journal of Science Education and Technology, 17(6), 560-565.

[39] Snoeyink, R., \& Ertmer, P. (2001). Thrust into technology: how veteran teachers respond. Journal of Educational Technology Systems, 30(1), 85-111

[40] Czarnecki, K. (2009). Digital storytelling in practice: Storytelling in context. Library Technology Reports, 45(7), 5-8.

[41] Yuksel, P., Robin, B. \& McNeil, S. (2011). Educational uses of digital storytelling all around the world. In M. Koehler \& P. Mishra (Eds.), Proceedings of Society for Information Technology \& Teacher Education International Conference 2011 (pp. 1264-1271). Chesapeake, VA: AACE

[42] Karakoyun, F. (2014). Examining the views of elementary school students and pre-service teachers about digital storytelling activities in online environment (Unpublished doctoral dissertation). Anadolu University, Institute of Educational Science, Eskişehir, Turkey.

[43] Tatum, M. (2009). Digital storytelling as a cultural-historical activity: Effects on information text comprehension (Unpublished doctoral dissertation), University of Miami.

[44] Yuksel, P. (2011). Using digital storytelling in early childhood education a phenomenological study of teachers' experiences (Unpublished doctoral dissertation), The Middle East Technical University.

[45] Dogan, B. \& Robin, B. (2008). Implementation of Digital Storytelling in the Classroom by Teachers Trained in a Digital Storytelling Workshop. In K. McFerrin Et al. (Ed.), Proceedings of Society for Information Technology \& Teacher Education International Conference 2008 (pp.902-907). Chesapeake, VA: AACE. 